\title{
特集 高齢者における外
}

\section{高齢者（70歳以上）の虚血性心疾患および合併他臓器 疾患手術の問題点 ${ }^{* *}$}

Coronary Artery Bypass Operation in Septuagenarians and the Problem of Non-cardiac Surgery with Ischemic Heart Disease

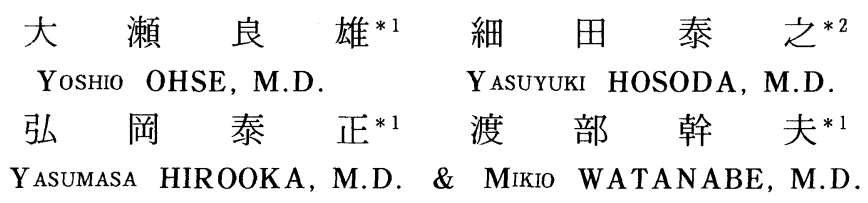

教室では昭和 50 年より, 虚血性心疾患に対する外科治療が行われているが, 年々手術患者の 高齢化が顕著になってきている. 初期の昭和 50 年当時の手術時平均年齢は $52.2 \pm 4.8$ 歳であった が, 昭和 61 年には手術時平均年齢は $60.4 \pm 8.4$ 歳である。乙のうち 70 歳以上の所謂高齢者は, 昭和 50 年から 58 年までの過去 9 年間で 3 例 $(0.7 \%)$ であったが, 昭和 59 年以降 2 年 7 力月間で 21 例 $(6.4 \%)$ と急増している. 今回は, 最近 2 年 7 力月間に教室で行った A-C Bypass 単独症例 326 例をもとに，70歳以上の高齢者群（A群-21例）と非高齢者群（B群-305例）を比較検討した. A 群では 3 枝病変例および左主幹部病変例が18例 $(85.7 \%)$ であったのに対し, B群では202例 $(66.2$ \%)であった. 術前の coronary risk factor を検討すると, A群では AMI の既往を有するも の, Hypertension, DM, Qwave, の出現しているものがB群䎲比して多く認められた. 手術は A群で患者一人平均 2.28 本 Bypass を行い, B群では2.24本のBypass を行った。手術成績はA 群に死亡例はなく満足すべきものであったが, B群で 3 例 $(0.9 \%)$ を失なった。術後 ICU 滞 在日数・在院日数を比較すると, A 群でやや延長を認めたが有意差を認めるまでにはいたらな かった. 虚血性心疾患と他藏器疾患を合併する手術については, 各々の疾患の重症度・緊急性 を十分に検討し, さらに厳重な循環動態のモニターによる監視のもとに, 症例によっては IAB $\mathrm{P}$ 装置等を用意し手術に臨むべきと考えている。

索引用語: 高齢者 (70歳以上), 虚血性心疾患, 大動脈一冠動脈バイパス, 合併他藏器疾患手術

key woeds: septuagenarian, Ischemic heart disease, aorto-coronary bypass, combined non-cardiac surgery

\section{はじめに}

*1 順天堂大学医学部胸部外科学教室講師 $\quad * 2$ 同教授

Department of Thoracic Surgery, Juntendo University, School of Medicine

** 第239回順天堂医学会学術集会 [Nov.15, 1986]

(Dec. 22, 1986受付)
最近の心臓外科は膜型人工肺の普及, 術中心筋 保謢法の改良や術前術後管理の向上により, 術後 経過を重篤にする合併症は以前に比べ減少し,よ り安全に手術が行われるようになってきた。

以前は高歯者ゆえに腎機能等全身の予備力がな 
く，人工心肺使用手術には耐えられないというこ とで, 手術適応から除外された症例でも, 最近で は積極的に手術が行われ成績も向上してきている. 特に高齢者に対する手術適応の拡大は, 狭心症・ 心筋梗塞症に対する Aorto-Coronary Bypass (以下A-C Bypass) や, 心室瘤切除などの虚血性 心疾患の手術で顕著になっている.

表 1 は, 昭和50年より当科で行った後天性心疾 患のうち虚血性心疾患765例, 弁膜疾患322例の手 術時年齢の年次別推移である. 昭和 50 年当時の虚 血性心疾患患者の手術時年齢は 45〜 57歳, 平均 52 . $2 \pm 4.8$ 歳, 弁膜疾患の場合は $22 \sim 39$ 歳, 平均 34.6 \pm 7.0 歳であったが, 昭和61年には虚血性心疾患患 者の手術時年齢は $36 〜 75$ 歳, 平均 $60.4 \pm 8.4$ 歳, 弁 膜疾患では $24 \sim 62$ 歳, 平均 $50.6 \pm 11.3$ 歳となり, 約 10 年間で10歳近くも平均年齢が上昇し, 特に虚 血性心疾患の場合には平均年齢で60歳を越える程 になってきた。乙の間の70歳以上の高齢者の手術 例は弁膜疾患ではなかったが，虚血性心疾患では 昭和 55 年に 1 例， 57 年 2 例，59年に 5 例， 60 年 7 例, 61 年は 7 力月間で既に 9 例と, 昭和 59 年以降 著明に増加している。

そこで今回は心臟外科手術のうち特に虚血性心 疾患に絞って高粟者の A-C Bypass 術と心疾患 合併他藏器疾患の外科治療について, 若干の文献 考察を加えて報告する.

\section{高齢者における虚血性疾患}

対象（表 2 ）は昭和59年以降の 2 年 7 力月間に, 教室で行った虚血性心疾患手術症例のうち A-C Bypass 単独症例の326例とした。 この326例のう ち70歳以上の高齢者群（以下A群）は21例で, 全 体の $6.4 \%$ を占めていた。 てれに対し69歳以下の症 例（以下B群）は305例であった。

$\mathrm{A}$ 群の年齢は70〜78歳, 平均72.1歳で男性 17 例, 女性 4 例である. B群の年齢は36〜 69 歳 平均 57.8 歳で, 男性269例, 女性36例である.

これらの症例を病型により分類する（表 3）と, A群では Stable angina 6 例, Stable angina +
表 1 後天性心疾患手術時年齢の年次推移

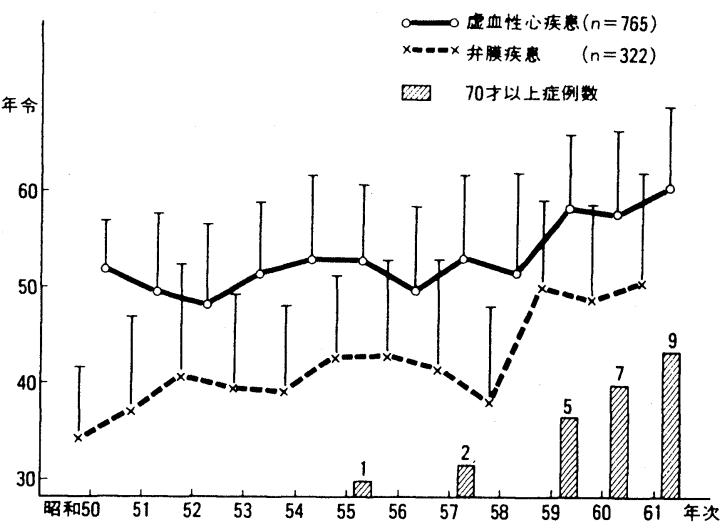

表 2 症例（S59.1.18～61.7.31）

\begin{tabular}{|c|c|c|}
\hline & 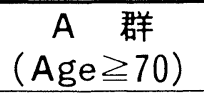 & $\begin{array}{c}\text { B } \quad \text { 群 } \\
(\mathrm{Age}<<70)\end{array}$ \\
\hline 症例数 & 21 例 & 305 例 \\
\hline 性 別 & $M \cdots \cdots 17$ 例 & $M \cdots \cdots 269$ 例 \\
\hline & $F \cdots \cdots, 4 "$ & $F \cdots \cdots \quad 36 "$ \\
\hline $\begin{array}{l}\text { 年 令 } \\
\text { (平均) }\end{array}$ & $\begin{array}{l}70 \sim 78 才 \\
(72.1 \text { 才) }\end{array}$ & $\begin{array}{l}36 \sim 69 才 \\
(57.8 \text { 才) }\end{array}$ \\
\hline
\end{tabular}

表 3 病型による分類（S59.1.18～61.7.31）

\begin{tabular}{l|c|c}
\hline & A 群 & B群 \\
\hline Stable Angina & 6 例 & 105 例 \\
Stable Angina + old M I & $7 \prime \prime$ & $123 "$ \\
Unstable Angina & $5 \prime \prime$ & $41 "$ \\
Unstable Angina + old M I & $2 \prime \prime$ & $28 \prime$ \\
AMI(Emergency op.) & $1 "$ & $8 \prime$ \\
\hline
\end{tabular}

表 4 Coronary Angiography 所見よりみた冠動脈 病変 $(\mathrm{S} 59.1 .18 \sim 61.7 .31)$

\begin{tabular}{l|r|r}
\hline & A 群 & B 群 \\
\hline 一枝病変 & 1 例 & 34 例 \\
二枝病変 & $2 " \prime$ & $69 "$ \\
三 枝病変 & $10 "$ & $165 "$ \\
L M T病変 & $8 \prime \prime$ & $37 "$ \\
\hline
\end{tabular}


old MI 7 例, Unstabe angina 5 例, Unstable angina + old MI 2例で, さらにAcute Myocardial Infarction(以下AMI)で緊急A-C Bypass 術を 行った症例は 1 例であった. B 群の各々は105例, 123例, 41例, 28例で, AMI により緊急 A-C Bypass 術を行った症例は 8 例であった。

術前の cineangiography 所見よりみた冠動脈 病変を比較する（表 4）と, A群では 1 枝病変例 1 例, 2 枝病変例 2 例, 3 枝病変例 10 例, 左主幹部 病変 (以下 LMT 病変) 例 8 例で, 重症例である 3 枝病変例と LMT 病変例を合わせると 18 例 $(85.9$ \%) であった。 これに対してB群の各々は 34 例, 69例, 165例, 37例でB群の 3 枝病変例と, LMT 病変例を合わせると 202 例 $(66.2 \%)$ である.

術前の coronary risk factor を検討する（表 5 ) と, A群では AMI の既往を有するもの, Hypertension, DM, Qwave の出現している症例がB 群に比較して多く, B群では Hyperlipidemia, Hyperuricemia, Smoking, Obesity, Family history が高率に認められた。

手術は全例, 中等度低体温完全体外循環下に心 筋保護法として, ice slush による Topical cooling c crystalloid cardioplegia 液を冠動脈 内に注入する心筋保護法を併用して行った。

A群では 1 枝 Bypass 2 例, 2 枝 Bypass 11例, 3 枝 Bypass 8 例に行い, 患者一人平均 2.28 本の A-C Bypass を行った. B群では各々49例, 143例, 103例で, さらに4枝以上の Bypass を行ったも のは10例で, 患者一人平均 2.24 本の A-C Bypass を行った（表 6 ).

手術成績（表 7 ）は, A群すなわち70歳以上の 症例に死亡例はなく, B群では術後肺炎による 1 例と術後 LOS による 1 例, および術後脳血管障 害を合併した 1 例の計 3 例を失い, 手術死亡率は $0.9 \%$ であった。

術後合併症（表 8 ）についてみると, A群では 上室性不整脈が最も多く5 例 $(23.8 \%)$ 亿認めら れ, 次いで心室性不整脈と Wound infection が 各々 2 例 $(9.5 \%)$, 肺合併症・脳血管障害および Perioperative Myocardial infarction (以下
表 5 術前のCoronary Risk factor

(S59.1.18 61.7.31)

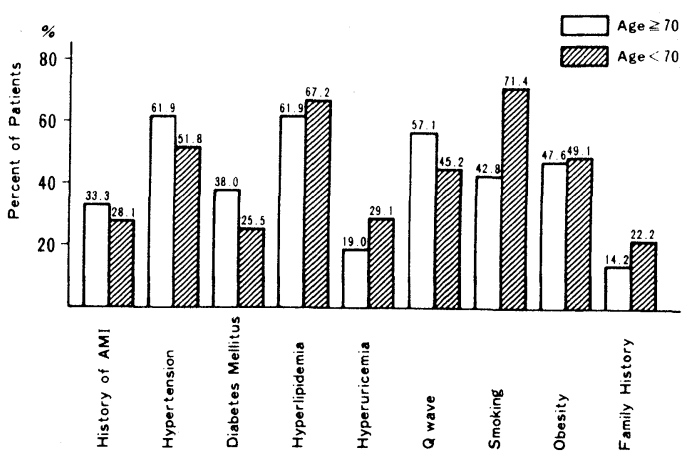

表 6 Aorto-Coronary Bypass 術々式

(S59.1.18 61.7.31)

\begin{tabular}{l|r|r}
\hline & A 群 & B 群 \\
\hline Single Bypass & 2 例 & 49 例 \\
Double Bypass & $11^{\prime \prime}$ & $143 \prime \prime$ \\
Triple Bypass & $8 \prime \prime$ & $103 \prime \prime$ \\
Quadruple Bypass & $0 \prime \prime$ & $10 \prime \prime$ \\
Mean graft & 2.28 本 & 2.24 本 \\
\hline
\end{tabular}

表 7 Aorto-Coronary Bypass 術の手術成績

(S59.1.18〜61.7.31)

\begin{tabular}{|c|c|c|c|}
\hline \multirow{2}{*}{$\begin{array}{l}\text { 年令 } \\
\text { (才) }\end{array}$} & \multirow{2}{*}{ 症例数 } & 死 & 亡 \\
\hline & & 数 & $\%$ \\
\hline$\leqq 39$ & 6 例 & 0 例 & $0 \%$ \\
\hline $40 \sim 49$ & $32 "$ & $0 "$ & $0 "$ \\
\hline $50 \sim 59$ & $135 "$ & $1 "$ & $0.7 " \prime$ \\
\hline $60 \sim 69$ & $142 "$ & $2 "$ & $1.4 "$ \\
\hline$<70$ & $21 "$ & $0 "$ & $0 \quad 11$ \\
\hline Total & 326 例 & 3 例 & $0.9 \%$ \\
\hline
\end{tabular}

PMI-術後心電図で, 新たにQwaveを認めた症 例）が各々 1 例 $(4.7 \%)$ であった。B群では上室 性不整脈 (10.4\%) が最も多く, 次いで肺合併症 $(8.5 \%)$, Wound infection $(7.2 \%)$, 心室性不整 脈 $(6.2 \%)$, PMIの発生 (3.6\%) の順で以下は表 8 
表 8 Aorto-Coronary Bypass 術術後合併症

(S59.1.18〜61.7.31)

\begin{tabular}{|c|c|c|c|c|c|}
\hline & $n^{A}$ & $\begin{array}{l}\text { f } \\
\%\end{array}$ & $\begin{array}{l}\text { 群 } \\
\%\end{array}$ & $n^{B}$ & $\begin{array}{c}\text { 群 } \\
\% \\
\end{array}$ \\
\hline \multicolumn{6}{|l|}{ Arrhythmia } \\
\hline 上室 性 & \multicolumn{3}{|c|}{5 例 $23.8 \%$} & 32 例 & $10.4 \%$ \\
\hline 心 室 性 & $2 "$ & 9.5 & $5 "$ & $19 \prime \prime$ & $6.2 "$ \\
\hline Wound infection & $2 "$ & & $5 "$ & $22 "$ & $7.2 "$ \\
\hline 肺 合併 症 & 11 & & $7 "$ & $26 "(1)$ & $8.5 "$ \\
\hline PMI(new $Q$ wave) & $1 "$ & & $7 "$ & 111 & $3.6 \prime$ \\
\hline Stroke & $1 "$ & & $7 "$ & $6 "(1)$ & $1.9 \prime \prime$ \\
\hline full recovery & $0 "$ & 0 & & $3 "$ & $0.9 \prime \prime$ \\
\hline major deficit & $1 ' \prime$ & 4.7 & $7 "$ & $2 "$ & $0.6 "$ \\
\hline Psychosis & $0 "$ & 0 & & $8 \prime$ & $2.6 \prime \prime$ \\
\hline 再開胸止血 & $0 "$ & 0 & $"$ & $7 "$ & $2.2 "$ \\
\hline IABP & $0 "$ & 0 & $"$ & $4 \prime(1)$ & $1.3 "$ \\
\hline Hepatitis & $0 "$ & 0 & , & $4 "$ & $1.3 "$ \\
\hline G-I Bleeding & $0 "$ & 0 & $"$ & $3 "$ & $0.9 "$ \\
\hline Septicemia & $0 "$ & 0 & $"$ & $1 "$ & $0.3 \prime$ \\
\hline
\end{tabular}

表 9 Aorto-Coronary Bypass 術術後在院日数

(S59.1.18〜61.7.31)

\begin{tabular}{l|c|c}
\hline & $A$ 群 & B 群 \\
\hline ICU滞在日数 & $7.5 \pm 3.1$ 日 & $6.3 \pm 5.4$ 日 \\
術後在院日数 & $30.2 \pm 11.4 ”$ & $27.2 \pm 13.9 \prime$ \\
\hline
\end{tabular}

の通りであった。

術後 ICU 滞在日数および在院日数を比較する (表 9 )と, A群では ICU 滞在日数が7.5 あったのに対し, B群では6.3土5.4日, 術後 ICU 滞在を含めた在院日数ではA群で $30.2 \pm 11.4$ 日, B 群 $27.2 \pm 13.9$ 日で術後 ICU 滞在日数, 術後在院 日数ともにA群でややながくなっていたが, 両群 間に有意差は認められなかった。

\section{心疾患合併他臟器疾患の手術}

次に虚血性心疾患に他藏器疾患を合併し, その 各々に対し外科治療を行った症例を呈示する。

症例：61歳男性 昭和56年頃より労作時に胸
痛が出現し, 某大学病院で狭心症と診断され内科 治療を受けていた。昭和60年 7 月胃部不快感を訴 え, 某大学病院で胃透視等の検査を受け早期胃癌 之診断された. 以前より狭心症と診断され投薬を 受けていた為に, 同年 9 月 cineangiography を 施行しその結果, RCA, LAD の完全閉塞と, CX の HL および PV 枝の $75 \%$ 狭窄を認めた。

左室機能は良好で入院と同時に, 内科治療を行 い全く症状はなくまず腹部手術を行うこととし， 同年10月胃切除術を施行した. 腹部手術後一度退 院したが, 約 6 力後に軽い胸痛発作が出現した為 に, 昭和61年 5 月に再度 cineangiography を行 い, 前回之同様の所見（図1）で手術適応を考え られた為に，同年 6 月当科にて LAD には左内胸 動脈を用い, RCA，CX の HL および PV 枝に は，大伏在静脈を用いて 4 枝 Bypass 術を行った。 A-C Bypass 術後は胸痛発作も全く消失し, 約 1 カ月後の Restudy (図2) でも Bypass Graft は 良好に開存し現在は農業に従事している. 図 2 左 は, LAD に対し左内胸動脈（LIMA）を用いて Bypass を行ったもので LAD の末梢まで十分に 造影されている. 図 2 中央は RCA, 図 2 右上は $\mathrm{HL}$, 図 2 右下は CX の PV 枝に対して大伏在静 脈(SVG)を用いて Bypass を行ったもので, 3 枝 ともに良好に開存し末梢まで造影されている。

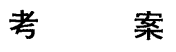

わが国でも人口構成の高齢化に伴い, 最近では 高齢者に対する A-C Bypass 術の報告1ん3がみ られるようになってきた. 高齢者の A-C Bypass 術の手術死亡率は, 施設により様々で 2 ～ $8 \%$ とい われ, ${ }^{4)(9)}$ Hochberg ${ }^{10}$ によれば高齢者の手術死亡 率は, 若年者の約 3 倍と報告している. しかしな がら, 近年は手術方法・麻酔法・心筋保護法や, 各種補助手段の改良・発達により, 高齢者に対す る冠動脈外科手術も積極的に行われるようになり， 成績も向上してきている.

手術の適応については, cineangiography 所見 による適応のほかに, 高齢者の場合には単なる生 


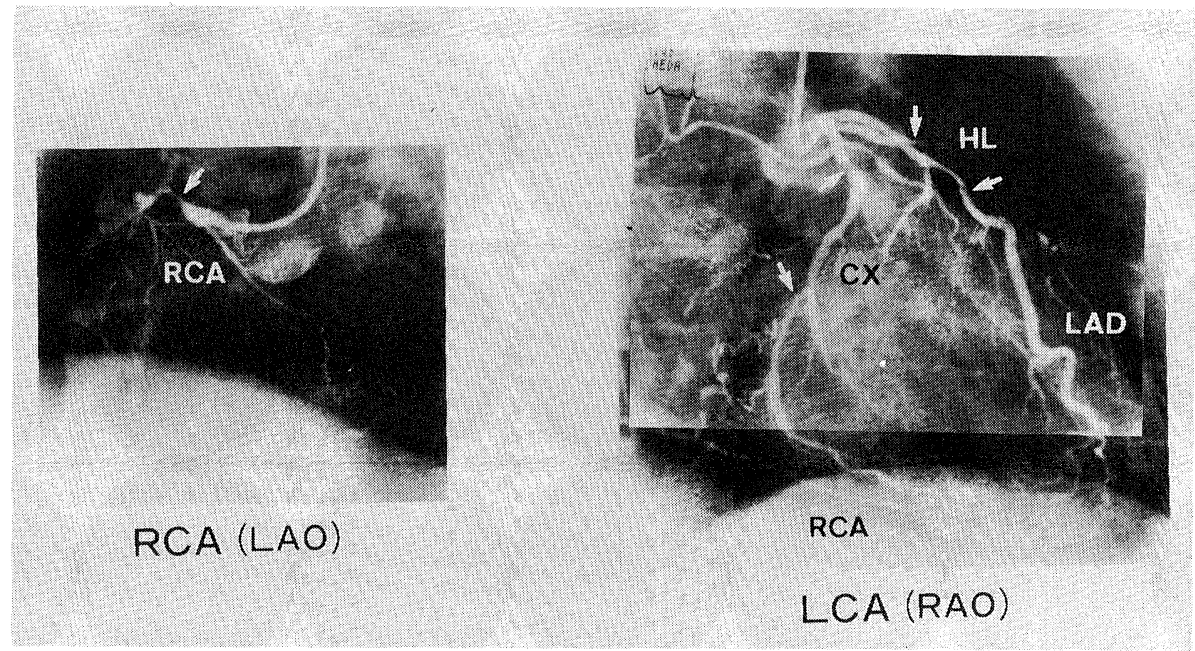

図 1 Cineangiography S.O. 61歳 男性

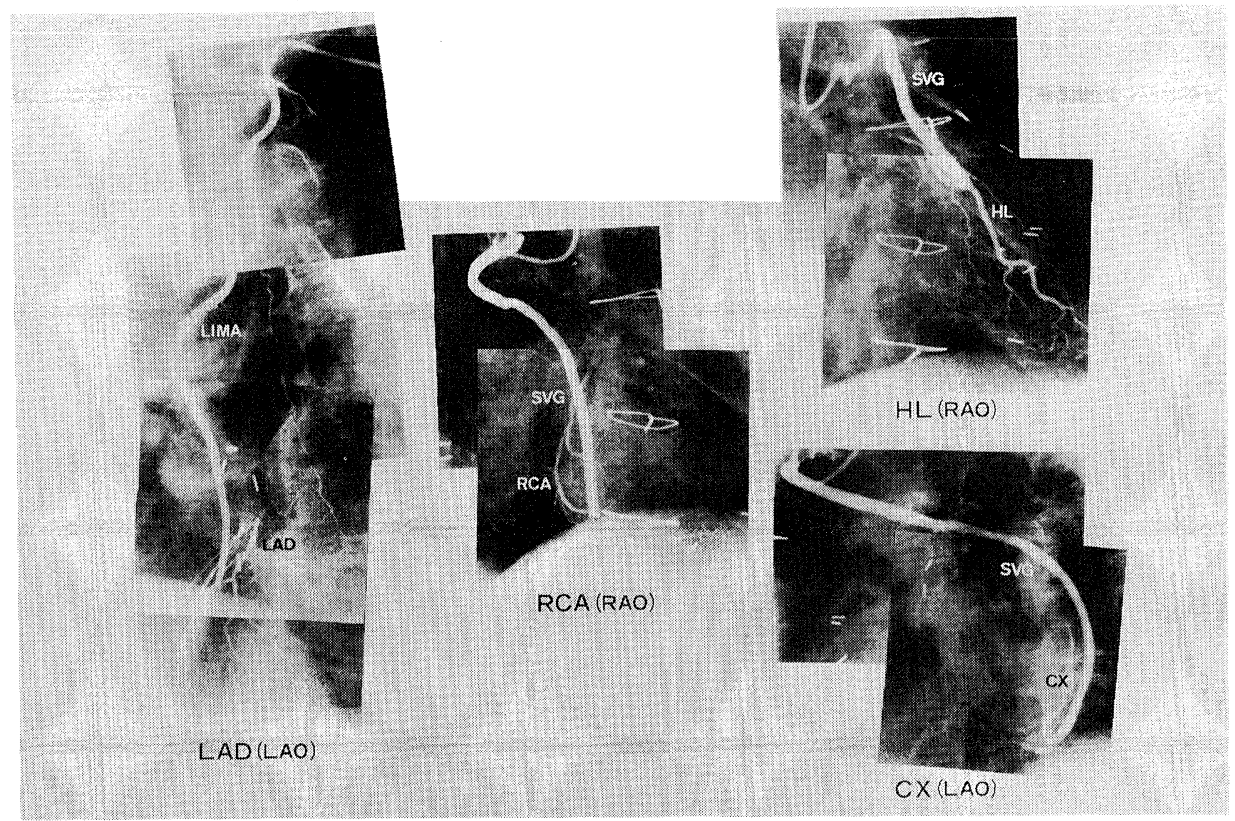

図 2 Cineangiography（Post op.Study）S.O. 61歳 男性 
活年齢（Chronological age）でなく, 生理的年 齢（Physiological age）を十分に考慮すべきで あるという意見が多く見られる. Dietamer ${ }^{9}$ 等は 生理的年齢を規定する要因として，1）狭心症の 発作以前の患者の activity，2）患者の精神状態, 特に Dementia semilis は手術の禁忌となる，3） 病気を治して社会に復帰したいという意欲，4） 慢性腎不全・高度な未梢血管障害・脳血管障害な ぞの, 重篤な合併症の有無などをあげている. 教 室でも高齢者の手術に際しては, 特に全身状態を 慎重に検討し,さらに患者自身の手術に対する意 志と, 手術後の社会生活に対する意欲と積極性の 有無が, 術後経過を大きく左右するものと考えて いる.

一方, 高歯者の冠動脈病変は自験例でもみられ る如く, LMT 病変や 3 枝病変を含む重篤な症例 が多く, また, 一般的に心臓以外の各種臟器の機 能低下, 予備力の低下が認められる. 従って, 常 に注意深い術後管理が必要で些細な術後合併症も 未然に防止し, 早期離床・早期退院を目標に治療 にあたることが最も重要と思われる.

一方, 虚血性心疾患に合併した他藏器疾患の外 科的治療については, 未だ報告(1) 13) も少なく今後 さらに検討が必要であるが, 一般的には各々の疾 患の重症度と緊急性を考え, どちらを優先するか 慎重に検討しなければならない。

一般外科的手術の手術時期より考えると, 心疾 患合併の如何にかかわらず, 緊急を要するものと 待期手術とがある。

緊急手術の場合で虚血性心疾患の合併が疑われ る場合, すなわち, 狭心症・心筋梗塞の既往, 心 不全の既往および心電図所見の異常を有する症例

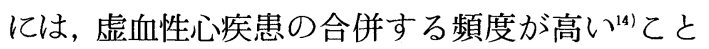
から, 緊急手術に際しては厳重な循環動態のモ二 ターが必要である.すなわち Swan-Ganz カテー テルの留置, ECGモニターによる監視, CVPの測 定, 血液ガス分析によるチェック, 抗不整脈郕・ 亜硝酸剤等の緊急時の薬剤の準備や, pace maker • IABP装置等をStand byして手術に臨むべきであ る.
待期手術の場合には時間的な余裕があり, 負荷 心電図や cineangiography による正確な術前心 機能の評価と冠動脈病変を把握し, 循環器内科医 ・ 胸部外科医・一般外科医と詳細に検討し, 結論を 出すべきである. 特に進行する悪性腫瘍について は, 原発臓器・生物学的悪性度・組織型・進行度 など検討し，さらに手術侵襲を考慮して，個々の 症例について術式を選択すべきである.

筆者の呈示した症例も，虚血性心疾患に合併し た悪性腫瘍の症例であるが, 術前に cineangiography を施行し, 冠動脈狭窄の程度・部位・左室機 能や病型を十分に検討し, 心疾患に対し内科治療 を積極的に行い，全身状態の改善と安定を得た後 に, 厳重な監視のもとに悪性腫瘍に対する手術 を行った，その後，体力の回復をまって約 6 力月 後に, 心疾患に対する手術, すなわち, 4 枝 Bypass 術を行い良好な結果を得た。

このような悪性腫瘍と心疾患の合併例は, 年齢 の高齢化や生活様式の変化に伴ない, 今後さらに 増加してくるものと思われる. 我々は原則的には 心疾患の安定が得られれば, 悪性腫瘍は進行する ものであり, 専門医の厳重な監視のもとに先に手 術を行うべきであると考えている.しかしながら， 心機能低下症例や左主幹部病変例, または症状 の不安定な症例の場合には, 心疾患の手術を先行 し心機能の回復をはかり，その後できるだけ早い 時期に, 悪性腫瘍に対する手術を行うべきである と考えている.

\section{まと め}

1）心疾患患者の手術時年歯の高齢化が著明と なり, 特に最近では虚血性心疾患患者の手術時平 均年齢は60歳をこえている。

2）高齢者の虚血性心疾患では，3枝病変例お よび左主幹部病変例等の重篤なものが $85.7 \%$ を占 めていた。

3）高齢者の虚血性心疾患患者21例に対し, A-C Bypass を行い死亡例はなかった。

4）心疾患の合併した他藏器疾患の手術に際し 
ては, 的確な病態の把握を行った上で各々の疾患 の, 重症度と緊急性を十分に検討して外科的治療 の方針を決定すべきである.

\section{文献}

1) 伴 敏彦：老年者虚血性心疾患の外科的療法の適応.

Geriat, Med, 21: 241 247, 1983

2) 末田泰二郎, 望月高明, 川上恭司, 他: 70歳以上の高 齢者に対する大動脈一冠動脈バイパス手術施行例の検 討. 広島医学, 38: 171 175, 1985

3）秋山一也, 遠藤真弘, 小柳 仁: 高齢者に対する冠 動脈外科的治療成績. 胸部外科, 35: 417 421，1982

4) William, S.K., John, S.D., Joseph, M.C., et al.: Efficacy of Coronary artery Bypass Grafting in Elderly Patients With Coronary artery Disease. Am. J. Cardiol, 47: 923 930, 1981

5) B. Eugene, B., Page, W.A., David, J.D., et al: Coronary artery Bypass Operation in Septuagenarians. Ann. Thorac. Surg., 31: 310 $\sim 313,1981$

6) Micheal, W.R., Joseph, G.S., Robert, E.K., et al.: Cardiac operation in patients over 80 years of age. J. Thorac. Cardiovasc. Surg., 90: $56 \sim 60,1985$

7) Joseph, M., Don, C.W., Walter, S.E., et al.: Coronary artery Bypass in Patients over 70
Years of Age: Indications and Result. Am. J. cardiol, $36: 342 \sim 345,1975$

8) Bernard, J.G., Richard, A.K., Robert, L.F., et al.: Coronary arteriography and Coronary Artery Bypass Surgery: Morbidity and Mortabity in Patients Age 65 Years or Older. Circulation, 67: 483 491, 1983

9) Dietamer, G., Cliff, C., Fnank J.H., et al.: Coronary artery bypass surgery in patients seventy years of age and older. J. Thorac. Cardiovasc. Surg., 73: 237 241, 1977

10) Hochberg, M.S., Levine, F.H., Willard, M.D., et al.: Isolated coronary artery bypass grafting in patient seventy years of age and older-Early and late results. J. Thorac. Cardiovasc. Surg., 84: 219〜223, 1982

11) 三品寿雄, 草島勝之, 高田憲一, 他: 心疾患に合併 した肺癌 - 食道癌の外科治療. 臨床胸部外科, 3: 679 $\sim 688,1983$

12）星野高伸, 鰐淵康彦, 青木啓一, 他: 重症心疾患合 併患者の開腹術に関する検討. 日臨外会誌，4: 351 355,1982

13）中尾量保, 宮田正彦, 中島信一, 他: 心疾患合併症 例の手術治療の問題点. 日臨外会誌, 4: 355 358, 1982

14）数井暉久, 小松作蔵, 佐々木 孝, 他: 動脈硬化性 血管病変における選択的冠動脈造影法の意義. 日胸外 会誌, 31: 440 445, 1983

抄 録

\section{之ネソタ州 Rochester 住民の冠状動脈性心疾患}

\section{第 7 報（1950年から 1982年までの発生）}

Coronary heart disease in residents of Rochester, Minnesota

VII. Incidence, 1950 through 1982

Elveback, L. R., Mayo Clin. Proc., 61:896 900, 1986

々ネソタ州 Rochester 住民の冠状動脈性心疾 患についての1982年までの新たな疫学調査の結果 が出た。死亡率が減少し始めた 1960 年代後半と最 近の冠状動脈性心疾患の年齢別調整発生率を比較 すると, 男子で $11 \%$ 減少しているのに対し.女子 で $9 \%$ 増加していた。乙の最も大きな男女差は, 冠状動脈性心疾患の初発症状として, 心筋硬塞の 発生頻度の変化に因ると乙ろが大きく, 男子では その率が $20 \%$ 減少しているが, 女子では $17 \%$ 増加 していたためであり，その最も大きな変化は50〜
69歳でみられた. 1965〜1969年の期間から1979年〜 1982年の期間まで初発症状別でみると, 突然死の 年齢別調整発生率は男女とも増加していた。

心筋硬塞による24時間以内及び 30 日以内の致死率 と突然死の発生率は一定していた。

冠状動脈性心疾患の発生状況における最近の傾 向に著明な男女差のあることの理由を解明すべく 追加調查が必要と思われる。

(病理学第一講座 米川仁朗) 